\title{
ASSESSM ENT OF RISK FOR THE FORM ATION OF PSYCHO-PHYSICAL DEVELOPM ENT AND SOMATIC HEALTH DISORDERS IN CHILDREN IN THE PRESCHOOL EDUCATIONAL ORGANIZATIONS WITH DIFFERENT REPRESENTATION OF GROUPS
}

\author{
O.Yu. Ustinova ${ }^{1,2}$, A.V. Alekseeva ${ }^{1}$, K.P. Luzhetsky ${ }^{1,2}$, O.A. Maklakova ${ }^{1,2}$, \\ Yu.A. Ivashova', V.G. Makarova' ${ }^{1}$, O.A. Kobyakova ${ }^{1}$ \\ ${ }^{1}$ FBSI "Federal Scientific Center for Medical and Preventive Health Risk Management Technologies", Russian \\ Federation, Perm, 82, M onastyrskaya St., 614045, \\ 2 FSBEI of Higher Professional Education "Perm State National Research University", \\ Russian Federation, Perm, 15, Bukireva St., 614990
}

We conducted the study of sanitary and hygienic conditions for the staying of children in the preschool educational organization with increased representation of groups. It was established that in the "compacted" preschool educational organizations ( 30 children in group) the area of playing rooms does not comply with requirements of SanPIN 2.4.1.3049-13; the acoustic exposure level reaches 75-80 dBA; the air of playing rooms contains phenol and formaldehyde in the concentrations exceeding the threshold level value for continuous exposure; and the bacterial load of the air of playing rooms, including the potentially pathogenic flora, increases significantly. The increased number of children in groups increases the risk of delays in the psycho-physical development of children and reduction of adaptive reserve of the cardiovascular, respiratory and nervous systems; increases the risk for formation of systemic multiple organ pathology that, in aggregate, contributes to the increased morbidity of children with allergic diseases of respiratory organs and skin, chronic inflammatory diseases of pharyngonasal cavity, bacterial intestinal and quarantine infections, functional disorders of nervous system and contact helminth infestations.

Key words: preschool educational organizations, representation of groups, sanitary and hygienic conditions, psychophysical and somatic health of children

The Resolution of the chief public health official of the Russian Federation No. 164 dd. December 20, 2010 approved SanPiN 2.4.1.2791-10 "Changes No. 1 to SanPiN 2.4.1.2660-10 "Sanitary and epidemiological requirements to the arrangement, content organization of work at preschool orgnizations"" which excluded the notion "threshold representation of group" (SanPiN 2.4.1.2660-10: for children in the age of 3-7 years - 15-20 persons in group) and established the provision on that the number of children in the groups of preschool educational organizations (PEOs) is de- termined as the area of group (playing) room per 1 child: not less than $2.5 \mathrm{~m}^{2}$ - for nursery groups and not less than $2.0 \mathrm{~m}^{2}$ - for preschool groups. The introduction of changes to the previously applicable SanPiN 2.4.1.2660-10 was stipulated by the significant deficit of places at PEOs of the Russian Federation. The implementation of SanPiN 2.4.1.2791-10, and in future - SanPiN 2.4.1.304913 (No. 28564 dd. May 29, 2013) allowed for signifiant reduction of queues to PEOs, but did not solve completely the problem of accessibility of places in the kindergartens and created new one 2015

(C) Ustinova O.Yu., Alekseeva A.V., Luzhetsky K.P., Maklakova O.A., Ivashova Yu.A., Makarova V.G., Kobyakova O.A., 64).

Ustinova Olga Yurievna - MD, Professor, Deputy director on clinical care (e-mail: ustinova@fcrisk.ru; tel.:+7 (342) 236-32-

Alekseeva Alla Vadimovna - mathematician of the systems and processes mathematical simulation department (e-mail: root@fcrisk.ru; tel. +7 (342) 237-18-04).

Luzhetsky Konstantin Petrovich - Candidate of Medical Sciences, Head of clinic of ecodependent and industrially con-ditioned pathology (e-mail: nemo@ fcrisk.ru; tel.+7 (342) 236-80-98).

Maklakova Olga Anatolievna - Candidate of Medical Sciences, Head of consulting and polyclinic department (e-mail: olga_mcl@fcrisk.ru; tel. +7 (342) 237-27-92).

Ivashova Yulia Anatolyevna - X-ray diagnostics department (e-mail: ivashova@ fcrisk.ru; tel.+7 (342) 237-27-92).

Makarova Venera Galimzyanovna - Allergist-Immunologist (e-mail: root@ fcrisk.ru; tel. +7 (342) -236-32-64).

Kobyakova Olga Alekseevna - candidate of medical science, head of admission office (e-mail: kobyakova@ fcrisk.ru; tel.+7 (342) 237-25-34). 
over-crowding of preschool organizations. In 2013 $40 \%$ of 56.4 thous. of working PEOs were overcrowded. Currently the average representation of PEOs in the Russian Federaiton is $106.4 \%$. Especially negative situation exists in the urban municipal kindergartens whee the representation of groups exceeds the permissible by $40.2 \%$, and in a number of regions this indicator is 2-3 times higher. Th biggest number of PEOs with over-crowded groups is located in the Republic of Bashkortostan (85.3\% of institutions), Yamal-Nenets Autonomous Area (77.9\%), Kurgan region (63.8\%), the Republic of Udmurtia (61.7\%) and Tomsk region $(53.4 \%)[2,10]$.

The results of sanitary-hygienic, epidemlogical and clinical studies conducted in the Russian Federation during the validity period of SanPiN 2.4.1.2791-10 with changes No. 1 and SanPiN 2.4.1.3049-13 demonstrated that the "compaction" of PEOs resulted in the worsening of the sanitary and hygienic conditions at the kindergartens [4, 12], decreased of the physical development indicators in children $[6,11,12]$, increase of their total morbidity $[1,9,13]$, reduction of the number of children with the first health group and finally - to the lower indicators of the educational process efficiency $[4,5,7,8]$.

Notwithstanding that on April 4, 2014 by the decision of the Supreme Court of the Russian Federation (No. AKPI14-281) the item 1.9 of SanPiN 2.4.1.3049-13 is acknowledged as partially inoperative the problem of the over-crowdness of groups at PEOs still exists, and this requires the objective assessment of the sanitary and hygienic situation in the groups with different representation and its impact on the health of children.

Materials and methods. For objective assessment of impact of the sanitary and hygienic situation in the groups with different representation on the indicators of physical and neuro-psychical development of children in the age of 3-7 years as well as the level of their somatic health we carried out the indepth study of children in two standard PEOs. The average representation of grous at PEO No. 1 was $29.3 \pm 2.0$ of children (observation PEO; total number of examined is 77); at PEO No. $2-22.0 \pm 3.0$ of children (comparison PEO; number of examined is 107). The observation group consisted of $19.5 \%$ of children of the youngest group (3-4 years), $28.5 \%-$ of the average group (4-5 years), 32.5\% - of the elder group (5-6 years) and $19.5 \%$ - preparatory (67 years). The comparison group consisted of $20.6 \%$ of children of the youngest group ( $\mathrm{p}=0.85$ to comparison group), $27.1 \%$ - of the average group ( $\mathrm{p}=0.83$ ),
$29.9 \%$ - of the elder group ( $p=0.71$ ) and $22.4 \%$ - of preparatory group $(p=0.64)$. The gender composition of examined children both as a whole $(p=0.87-$ $0.98)$ and in the separate age groups $(p=0.63-0.99)$ did not have the statistically significant differences.

The clinical and laboratory examination of children was carried out in accordance with ethical principles specified in Helsinki Declaration (1975, as amended 1983) and the National Standard of the Russian Federation GOST-R 52379-2005 "Good Clinical Practice" (ICH E6 GCP) and guidances of the State Sanitary Epidemiological Surveillance Service of the Russian Federation [8].

During the study we used the sanitary and hygienic (assessment of the level of contamination of air at the playing premises of pEOs and atmospheric air with industrial organic substances, studying the intensity of acoustic exposure, parameters of microclimate, bacterial contamination of the air of playing rooms), chemical and analytical (determining the content of phenol and formaldehyde in the atmospheric air and the air of playing premises at PEOs), epidemiological (retrospective analysis of the morbidity of children visiting the examined PEOs), clinical, functional (spirography, rhinomanometry, cardiointervalography) and instrumental methods (ultrasonic scanning of abdominal cavity organs) examination and medical-social questioning. All the studies were performed using the standard unified techniques. The information is analyzed with the help of statistical methods (Statistica 6.0). The two-sample Student criterion was used to compare the groups under the quantitative parameters. The dependences between the parameters were assessed using the methods of unifactor dispersion and correlation-regression analysis.

Results and their discussion. The comparative analysis of protocols of the cheduled inspections in relation to the examined PEOs by the territorial body of Rospotrebnadzor demonstrated that under the conditions of location, equipment, arrangement of territories, characterization of buildings, level of artificial and natural illumination, air and heat conditions, water supply and sewage, medical services, day regimen, organization of nutrition and educational process both kindergartens meet the requirements of SanPiN 2.4.1.3049-13 and have no significant differences $(p=0,89-0,15)$. In addition, the conducted sociological studies allowed for establishing that under the material situation, social and domestic conditions, medical characteristics (heredity, chronic diseases in children, etc.) the families of 
children visiting the examined PEOs were comparable between each other $(p=0.89-0.62)$.

At the same time, during the chemical and analytical study of the quality of air at the playing premies it was established that the average daily concentrations of formaldehyde $(0.0215 \pm 0.0043$ $\left.\mathrm{mg} / \mathrm{m}^{3}\right)$ and phenol $\left(0.0138 \pm 0.0034 \mathrm{mg} / \mathrm{m}^{3}\right)$ in the air of obdervation PEO by 1.5-2.0 times exceeded the same indicators for comparison PEO $\left(0.0142 \pm 0.0028\right.$ and $0.0070 \pm 0.0017 \mathrm{mg} / \mathrm{m}^{3}$ respectively; $p \leq 0.0001)$. It should be noted that the results of parallel analysis of the quality of atmospheric air at the locations of examined PEOs allowed for establishing that the average daily concentrations of formaldehyde (0.002-0.003 $\left.\mathrm{mg} / \mathrm{m}^{3}\right)$ and phenol $\left(\leq 0.004 \mathrm{mg} / \mathrm{m}^{3}\right)$ were close to each other and in both cases complies with hygienic standards (formaldehyde - average daily maximum permissible concentration $=0.01 \mathrm{mg} / \mathrm{m}^{3}$, $p \leq 0.001$; phenol - average daily maximum permissible concentration $=0.003 \mathrm{mg} / \mathrm{m}^{3}, p \leq 0.05$ ). The results of correlation and regression analysis demonstrated that the content of formaldehyde and phenol in the air of playing premises did not depend on their concentration in the atmospheric air. Analyzing the possible source for the intake of these chemical substances to the air of PEO playing premises it should be noted that according to numerous studies the materials used for the construction of buildings and decoration of internal premises as well as the furniture can be the sources of emission to environment of some toxic impurities, including formaldehyde and phenol $[3,13,14]$.

The results of field measurements of the level of acoustic impact on children in the playing premises demonstrated that at the observation PEO the value of equivalent and maximum noise during playing lessons reached $77.8-78.5 \mathrm{dBA}$ that credibly exceeded the same indicators at comparison PEO (63.0-65.8 dBA, $p=0.036-0.001$ ). During the day regimen chronometry it was established that the duration of playing lessons for children in both kindergartens during daytime is 3.5-4.0 hours $(p=0.73)$.

Studying the bacterial content in the air of playing premises as the sanitary indicator of the air environment conditon in the group cells demonstrated that alreaady at $10-11$ AM the total microbial count at observation PEO reached $1360.91 \pm 550.49 \mathrm{CFU} / \mathrm{m}^{3}$ (in relation to $1151.67 \pm 688.76 \mathrm{CFU} / \mathrm{m}^{3}$ at comparison $\mathrm{PEO}$, $p=0,61$ ), herewith $30 \%$ of samples contained the opportunistic flora (St. aureus) with microbial count 4-20 CFU $/ \mathrm{m}^{3}$ (no St. aureus at comparison PEO, $p=0.04)$. We established the direct correlation relationship between the total microbial count for the bacterial content of the air of premises of group cells and the content of opportunistic flora in the air (St. aureus) $\left(R^{2}=0.69 ; p=0.001\right)$.

The indicators of microclimate (temperature conditions and relative air humidity) of both examined PEOs complied with hygienic standards established by SanPiN 2.4.1.3049-13 and did not differ between each other ( $p=0.81-0.96)$.

Based on the results of retrospective (20102013) comparative analysis of data on the application for medical assistance it was established that the children visiting the observation PEO by 1.23.6 often suffred from bronchial asthma, bacterial intestical and quarantine (chicken pox, scarlet fever) infections, chronic inflammatory diseases of rhinopharynx and tonsils, enterobiasis $(p=0.0016$ 0.05 ), and the cases of unspecified forms of allergic reactions, allergic conjunctivitis, viral verrucas, stomatitis, virus conjunctivitis were registered only in children visiting PEOs with high representation of groups. It should be noted that at the observation PEO the indicator of the morbidity of children with atopic dermatitis exceeded the average Russian indicator by 5.6 times (9911.0 versus 1778.4 of cases per 100000 of children), chronic diseases of tonsils and adenoids - by 2.9 times (4310.0 versus 1480.0), acute serous otitis media - by 3.6 times (10350.1 verus 2911.0). We established the direct correlation relationship between the morbidity of children with allergic diseases of respiratory organs $\left(R^{2}=0.39 ; p \leq 0.0001\right)$, herpetic infection of mucous membrane and other forms of stomatitis $\left(R^{2}=0.32 ; p=0.015\right)$, atopic dermatitis $\left(R^{2}=0.87\right.$; $p=0.005)$, functional intestinal disorders and dyspepsia $\left(R^{2}=0.74-0.84 ; p=0.009-0.035\right)$, acute serous otitis media $\left(R^{2}=0.79 ; p=0.018\right)$ and the representation of groups.

The comparative analysis of the results of somatometric studies demonstrated that in children of the observation PEO the relative risk of disorders in the growth rates and annual increase of body weight, frowziness of development and deficit of weight is 1.5-2.2 times higher than in the children of comparison PEO $(O R=1.54-2.24 ; D I=1.13-3.01$; $p=0.02-0.03)$. The established the direct correlation relationship between the group representation indicator and the number of children with disharmonious physical development $\left(R^{2}=0.25-0.38\right.$; $p=0.02-0.0001)$. In addition, under the results of assessment of the dental formula condition we established that the relative risk of the biological maturity 
disorders in children visiting the groups with high representation is by 1.5 times higher than the same in the children of comparison PEO $(O R=1.51$; $D I=1.11-1.96 ; p=0.01$ ).

When carrying out the functional study of the ardiovascular system condition it was stablished that the average group value of systolic and diastolic blood pressure in all the analyzed age groups did not have the credible differences between each other $(p=0.16-0.81)$ and complied with physiological age standard $(p=0.38-0.92)$. At the same time, the relative risk of the episodic arterial hypertension development in children of the observation PEO was by 10 times higher than at the comparison PEO $(O R=10.11 ; D I=4.23-18.81 ; p=0.01)$. The study of medium hemodynamic arterial blood pressure as the integral indicator reflecting the condition of post-load on the cardiac muscle of left ventricle demonstrated that the observation PEO children tend to higher values achieving the degree of statistical significance $(p=0.04)$ in the elder age groups (table 1). It should be noted that at the comparison PEO only $4.8 \%$ of children had medium hemodynamic arterial blood pressure above $85 \mathrm{Mmhg}$, since at the observation PEO the number of such children reached $19.2 \%(p=0.002)$. The relative risk of the vascular tone regulation disorders in the observation PEO children was by 4.0 times higher than at the comparison PEO

( $D I=2.11-7.41 ; p=0.01)$. The average group heart rate indicators in the children of different age groups of the examined kindergartens complied with age standards $(p=0.58-0.99)$, however at the observation PEO in the elder children they were credibly higher $(97.8 \pm 4.7$ beats per minute) than the indicators of the same age group at the comparison PEO $(88.0 \pm 4.0$ beats per minute, $p=0.008)$. We established the direct correlation relationship between the representation of groups and increase of heart rate in children $\left(R^{2}=0.36 ; p=0.03\right)$.

The endurance ratio (fitness) of the cardiovascular system in relation to loads in all the age groups of examined PEOs did not have any credible differences between each other $(p=0.41-0.61)$, however in the elder and preparatory groups it credible exceeded the physiological standard $(p=0.0001-0.02)$ that evidences the insufficient development of the functional reserves of cardiovascular system in the modern preshol children (table 2). At the same time, at the observation PEO the statistically credible delay in the functional maturity of cardiovascular system from the physiological level occurred already in the children of 4-5 years old (average group) $(p=0.01)$, since at the comparison PEO the credible differences with standard are established in the children older than 5 years (elder group) $(p=0.0001) \quad($ table 2).

Table 1

Indicators of medium hemodynamic arterial blood pressure in the examined chidren (Mmhg)

\begin{tabular}{|l|c|c|c|}
\hline \multirow{2}{*}{ Group } & \multicolumn{2}{|c|}{ PEO } & $\begin{array}{c}\text { Credibility of differences between } \\
\text { groups }\end{array}$ \\
\cline { 2 - 3 } & comparison & observation & 0,17 \\
\hline Youngest & $65,45 \pm 3,91$ & $70,49 \pm 6,50$ & 0,99 \\
\hline Average & $71,81 \pm 3,17$ & $71,84 \pm 5,13$ & $\mathbf{0 , 0 4}$ \\
\hline Elder & $67,47 \pm 3,56$ & $73,89 \pm 5,35$ & $\mathbf{0 , 0 4}$ \\
\hline Preparatory & $68,85 \pm 2,24$ & $75,02 \pm 3,52$ & \\
\hline
\end{tabular}

Table 2

The endurance ratio (fitness) of the cardiovascular system in the examined children (conventional units)

\begin{tabular}{|c|c|c|c|c|c|}
\hline \multirow{3}{*}{ Group } & \multirow{2}{*}{\multicolumn{2}{|c|}{ PEO }} & \multirow{3}{*}{ Age standard } & \multicolumn{2}{|c|}{ Credibility of differences } \\
\hline & & & & \multirow{2}{*}{ between groups } & \multirow{2}{*}{ group indicators with standard } \\
\hline & comparison & observation & & & \\
\hline Youngest & $30,76 \pm 2,49$ & $31,67 \pm 2,45$ & 30 & 0,61 & $0,53-0,20$ \\
\hline Average & $30,69 \pm 2,12$ & $31,93 \pm 2,44$ & 29 & 0,45 & $0,12-\mathbf{0 , 0 1}$ \\
\hline Elder & $31,06 \pm 2,93$ & $29,41 \pm 2,72$ & 25 & 0,41 & $0,0001-0,0019$ \\
\hline Preparatory & $29,66 \pm 1,67$ & $28,32 \pm 5,64$ & 23 & 0,60 & $0,001-0,02$ \\
\hline
\end{tabular}

In general, the relative risk of disorders in the rates of development of the functional abilities of cardiovascular system (adaptive reserve) in the observation PEO children was 1.4 times higher $(D I=1.11-$ $2.07 ; p=0.03$ ).
The results of calculation of the average group indicators for the systolic (beating) heart volume in the examined children demonstrated that their values in the relevant age groups did not have any credible differences $(p=0.08-0.71)$ between each other and differ from the age standard - 
$27.43-43.68 \mathrm{ml}(p=0.38-0.89)$. However, if at the comparison PEO the number of children with the systolic heart volume indicator below the physiological standard was only $2.9 \%$, at the comparison PEO their number reached $16.4 \% \quad(p=0.001)$; the relative risk of the heart beating volume reduction in the observation PEO children is 6 times higher than at the comparison PEO $(O R=6.67 ; D I=3.84$ 11.15; $p=0.01$ ) (table 3).

During the study the calculation of the minute blood volume (MBV) was performed for all the children. The average group MBV values in all the age groups did not have any credible differences
( $p=0.08-0.71$ ), however in the youngest and average groups they exceeded the physiological standard that is the reflection of adaptation processes of younger children to the staying at the organized team (table 4). At the same time the observation PEO had only $3.9 \%$ of children with MBV indicator belowe the permissible values, since the comparison PEO had $8.2 \%(p=0.22)$; the relative risk of MBV indicator decrease in the observation PEO children was more than 2 times higher than the same at the comparison PEO $(O R=2.25 ; D I=1.28-$ $3.93 ; p=0.03)$.

Table 3

Indicators of systolic (beating) heart volume in the examined children (ml)

\begin{tabular}{|l|c|c|c|}
\hline \multirow{2}{*}{ Group } & \multicolumn{2}{|c|}{ PEO } & \multirow{2}{*}{ Credibility of differences between groups } \\
\cline { 2 - 3 } & comparison & observation & 0,08 \\
\hline Youngest & $39,24 \pm 2,84$ & $35,80 \pm 3,23$ & 0,41 \\
\hline Average & $37,04 \pm 2,37$ & $35,30 \pm 3,66$ & 0,71 \\
\hline Elder & $39,61 \pm 2,36$ & $40,38 \pm 3,44$ & 0,64 \\
\hline Preparatory & $42,39 \pm 1,57$ & $40,42 \pm 11,25$ & \\
\hline
\end{tabular}

Table 4

Minute blood volume indicators in the examined children (1/min)

\begin{tabular}{|l|c|c|c|c|c|}
\hline \multirow{2}{*}{ Group } & \multicolumn{2}{c|}{ PEO } & \multirow{2}{*}{$\begin{array}{c}\text { Physiological } \\
\text { standard }\end{array}$} & & \multicolumn{2}{c|}{ Credibility of differences } \\
\cline { 2 - 2 } \cline { 5 - 5 } & comparison & observation & & between groups & with physiological standard \\
\hline Youngest & $3,69 \pm 0,35$ & $3,30 \pm 0,30$ & \multirow{2}{*}{$2,92 \pm 0,51$} & 0,08 & $\mathbf{0 , 0 0 1}$ \\
\cline { 1 - 2 } \cline { 5 - 6 } Average & $3,34 \pm 0,21$ & $3,45 \pm 0,36$ & & 0,58 & $\mathbf{0 , 0 0 1}$ \\
\hline Elder & $3,71 \pm 0,30$ & $3,64 \pm 0,24$ & \multirow{2}{*}{$3,39 \pm 0,61$} & 0,71 & $0,35-0,45$ \\
\hline Preparatory & $3,72 \pm 0,20$ & $3,44 \pm 0,87$ & & 0,40 & $0,31-0,88$ \\
\hline
\end{tabular}

As a result of study of the processes of excitability, conductivity and automatic action of cardiac muscle it was established that the deviations from the physiological standard are recorded for more than one half of the observation PEO children $(55.9 \%)$, since at the comparison PEO - only in $36.7 \%(p=0.02)$ (table 5). The most often type of pathology was the disorders of excitability established in $34.5 \%$ of the observation PEO children and $54.2 \%$ of the comparison PEO children $(p=0.006)$; herewith the sinus arrhythmia specific for children in the age of 3-7 years was recorded with close frequency (26.7 versus $30.5 \%, p=0.61$ ), since the sinus tachycardia was recorded 4 times often in the observation PEO children (23.7 versus $5.6 \%, p=0.001)$. We established the direct correlation relationship between the representation of groups and the frequency of registration of the cardiac muscle excitability disorders in children $R^{2}=0.34 ; p=0.02$ ), and the relative risk of their occurrence in the observation PEO children was 2.5 times higher $(O R=2.48 ; D I=1.17-4.21 ; p=0.01)$.

Table 5

Conditions of the processes of excitability, conductivity and automatic action of cardiac muscle in the examined children $(\%)$

\begin{tabular}{|l|c|c|c|}
\hline \multirow{2}{*}{ Electrocardiography data } & \multicolumn{2}{|c|}{ PEO } & $\begin{array}{c}\text { Credibility of differences between } \\
\text { groups }\end{array}$ \\
\cline { 2 - 4 } & comparison & observation & $\mathbf{0 , 0 2}$ \\
\hline Standard & 63,3 & 44,1 & $\mathbf{0 , 0 2}$ \\
\hline Deviations from standard & 36,7 & 55,9 & $\mathbf{0 , 0 0 1}$ \\
\hline Sinus tachycardia & 5,6 & 23,7 & 0,61 \\
\hline Sinus arrhythmia & 26,7 & 30,5 & 0,25 \\
\hline Sinus bradycardia & 2,2 & - & 0,83 \\
\hline Restricted blocking of the right Gis leg & 2,2 & 1,7 & \\
\hline
\end{tabular}


Table 6

Rhinomanometry indicators in the examined children $\left(\mathrm{cm}^{3} / \mathrm{s}\right)$

\begin{tabular}{|l|c|c|c|}
\hline \multirow{2}{*}{ Indicator } & \multicolumn{2}{|c|}{ PEO } & \multirow{2}{*}{ Credibility of differences between groups } \\
\cline { 2 - 4 } & comparison & observation & $\leq \mathbf{0 , 0 0 1}$ \\
\hline exp_left & $125,02 \pm 63,25$ & $103,39 \pm 60,80$ & $\leq \mathbf{0 , 0 0 1}$ \\
\hline exp_rigth & $153,43 \pm 33,32$ & $90,02 \pm 40,45$ & 0,22 \\
\hline insp_left & $126,82 \pm 58,51$ & $113,30 \pm 67,63$ & $\mathbf{0 , 0 1 1}$ \\
\hline insp_rigth & $124,21 \pm 30,81$ & $101,27 \pm 48,08$ & $\mathbf{0 , 0 4}$ \\
\hline summ_left & $251,84 \pm 56,38$ & $216,69 \pm 67,32$ & $\leq \mathbf{0 , 0 0 1}$ \\
\hline summ_rigth & $277,64 \pm 42,06$ & $191,29 \pm 46,39$ & $\leq \mathbf{0 , 0 0 1}$ \\
\hline summ_flow & $529,48 \pm 51,32$ & $407,98 \pm 56,73$ & \\
\hline
\end{tabular}

The complex comparative assessment of the respiratory system functional condition was performed under the results of somatometry, indicator of chest excursion at deep breathing and expiration, rhinomanometry and spirography data. During somatometry studies it was established that in $56.5 \%$ of the observation PEO children the chest circumference was below the physiological age standard, since at the comparison PEO the number of such children was only $31.32 \%(p \leq 0.001)$. The average group chest excursion indicators did not have the credible differences in the same age groups of compared PEOs $(p=0.34-0.8)$ and complied with "average results". At the same time, the number of children with low chest excursion apmplitude (less than $5 \mathrm{~cm}$ ) at the comparison PEO was 1.5 times lower than at the observation PEO (21.7 versus $31.76 \%$ respectively; $p=0.13$ ). The relative risk for the respiratory muscles development disorders in the observation PEO children by more than 1.5 times exceeded the same at the comparison PEO (OR=1.64; $D I=1.21-2.11 ; p=0.04)$. The results of rhinomanometry demonstrated that the total air flow in the comparison PEO children was $529.48 \pm 51.32 \mathrm{~cm}^{3} / \mathrm{s}$ that did not have any statistically significant differences from the physiological standard $\left(500-800 \mathrm{~cm}^{3} / \mathrm{s} ; p=0.67\right)$, but was credibly higher than the same indicator in the observation PEO children $\left(407.98 \pm 56.73 \mathrm{~cm}^{3} / \mathrm{s}\right.$; $p \leq 0.001)$. It should be noted that in the observation PEO children not only the total air flow but also all the volume indicators of the right and left nasal sections (at breating and expiration) were credibly lower than the same in the comparison PEO children ( $p \leq 0.001-0.04)$ (table 6). In general, the nasal passability disorders were established only in $8.7 \%$ of the comparison PEO children, since the number of such children at the observation PEO was $43.8 \%$ $(p \leq 0.001)$. The relative risk of the nasal breathing disorders development in the children visiting PEOs with high representation of groups by more than 7 times exceeds the same at the comparison PEO $(O R=7.77 ; D I=2.41-13.88 ; p=0.02)$.

Study of the functional condition of the low respiratory tracts using the spirography method did not reveal any significant differences: more than $80 \%$ of examined had the rated level of the spirogram indicators $(p=0.88)$; for $17.1 \%$ of children at the observation PEO and $16.1 \%$ of children at the comparison PEO $(p=0.88)$ we established the restrictive disorders which were slightly manifested; no obstructive disorders were recorded for any child.

The comparative assessment of the functional condition of vegetative nervous system was performed under the results of cardiointervalography: the prevailing type of initial vegetative tone in the comparison PEO children included eitonia (67.0\%), since in the observation PEO children this option was present only in $33.5 \%(p \leq 0.001)$ (table 7$)$. The vagotonic and simpatico-tonic options in the comparison PEO children were found with the same frequency $-11.5 \%$, and the hypersimpatico-tonic type was not recorded for any child. At the observation PEO the vagotonic option of initial vegetative tone was found 3 times often $(33.5 \%, p \leq 0.001)$, and the hypersimpatico-tonic type was registered in $11.5 \%$ of children $(p \leq 0.001)$ (table 7).

During the ortostatic test performance it was established that the prevailing type of vegetative reactivity in the comparison PEO children included the physiological simpatico-tonic option registered in $83 \%$, at the observation PEO it was found 1.7 times more seldom $(50 \%, p \leq 0.001)$ (table 8). At the same time, the observation PEO children 2.9 times often had the hypersimpatico-tonic option of vegetative reactivity (50 versus $17 \%, p \leq 0.001$ ) which is ensured by the high tone of humoral and metabolic impacts and, therefore, represents the regulation mechanism which is unprofitable for body in terms of energy. The relative risk for development of the hypersimpatico-tonic option of vegetative reactivity in the observation PEO children was 5 times higher than at the comparison PEO $(O R=5.0$; 
$D I=2.81-9.11 ; p=0.03)$. No asimpatico-tonic type of vegetative reactivity at which the expected stress of adaptive and compensatory mechanisms is absent is registered in the examined children of both kindergartens.

The results if comparative assessment of the cognitive functions maturity demonstrated that under the level of development of perception function, spatial praxis and kinesthetic organization of movements no principal differences between the children of the examined PEOs are established $(p=0.21-0.4)$, however it should be noted that the level of development of spatial praxis and kinesthetic organization of movements in the children of both examined PEOs was credibly lower than the physiological standard $(p=0.001-0.038)$ (table 9).

The analysis of resuts of the attention function assessment demonstrated that the average group assessment score in the comparison PEO children complied with physiological standard (6-8 points) and was $6.07 \pm 0.64$ of points, since at the observation PEO it did not exceed $4.12 \pm 1.22$ of points and was credibly low than the physiological standard $\quad(p=0.012) \quad$ (table $\quad 9)$.

Condition of initial vegetative tone in the examined children (\%)

\begin{tabular}{|c|c|c|c|}
\hline \multirow{2}{*}{ Indicator } & \multicolumn{2}{|c|}{ PEO } & \multirow{2}{*}{$\begin{array}{c}\text { Credibility of differences between } \\
\text { groups }\end{array}$} \\
\hline & comparison & observation & \\
\hline Vagotonia & 11,5 & 33,5 & $\leq 0,001$ \\
\hline Eitonia & 67 & 33,5 & $\leq \mathbf{0 , 0 0 1}$ \\
\hline Sympathicotonia & 11,5 & 11,5 & 1,0 \\
\hline Hypersympathicotonia & 0 & 11,5 & $\leq \mathbf{0 , 0 0 1}$ \\
\hline
\end{tabular}

Table 8

Types of vegetative reactivity in the examined children (\%)

\begin{tabular}{|c|c|c|c|}
\hline \multirow{2}{*}{ Type of vegetative reactivity } & \multicolumn{2}{|c|}{ PEO } & \multirow{2}{*}{$\begin{array}{c}\text { Credibility of differences between } \\
\text { groups }\end{array}$} \\
\hline & comparison & observation & \\
\hline Asimpatico-tonic & 0 & 0 & - \\
\hline Simpatico-tonic & 83 & 50 & $\leq 0,001$ \\
\hline Hypersimpatico-tonic & 17 & 50 & $\leq 0,001$ \\
\hline
\end{tabular}

Table 9

Results of assessment of the cognitive functions development degree in the examined children (points)

\begin{tabular}{|c|c|c|c|c|c|}
\hline \multirow{2}{*}{ Assessment } & \multicolumn{2}{|c|}{ PEO } & \multirow{2}{*}{$\begin{array}{l}\text { Credibility of dif- } \\
\text { ferences between } \\
\text { groups }\end{array}$} & \multirow{2}{*}{$\begin{array}{c}\text { Physiological } \\
\text { standard }\end{array}$} & \multirow{2}{*}{$\begin{array}{r}\text { Credibility o } \\
\text { differences } \\
\text { with standard }\end{array}$} \\
\hline & comparison & observation & & & \\
\hline Perception & $8,36 \pm 0,96$ & $9,06 \pm 1,02$ & 0,3 & $6-8$ & 0,9 \\
\hline Spatial praxis & $2,68 \pm 0,21$ & $2,56 \pm 0,39$ & 0,4 & $0-1$ & $\leq \mathbf{0 , 0 0 1}$ \\
\hline Kinesthetic organization of movements & $1,86 \pm 0,52$ & $2,25 \pm 0,36$ & 0,21 & $0-1$ & $0,038-0,001$ \\
\hline Attention & $6,07 \pm 0,64$ & $4,12 \pm 1,22$ & 0,005 & $6-8$ & $0,4-\mathbf{0 , 0 1 2}$ \\
\hline
\end{tabular}

The comparative analysis of the number of children with low level of the cognitive functions development demonstrated that 12.5 to $37.5 \%$ of children of the examined PEOs could not perform the tasks for spatial praxis, kinesthetic organization of movements and perception $(p=0,7-0,97)$, since in relation to the attention assessment test the number of such children was from $36.4 \%$ (comparison PEO) to $56.3 \%$ (observation PEO, $p=0.02$ ) (table 10). The relative risk of delay in the attention function developme for children visiting PEOs with high representation of groups more than 1.5 times exceeded the same at the comparison PEO $(O R=1.67 ; D I=1.91-3.88 ; p=0.02)$.
The comparative assessment of the somatic status in the children of examined PEOs is performed under the results of clinical examination of children by pediatrician, allergologist, ENTdoctor, gastroenterologist and neurologist, data of the ultrasound examination of the gastrointestinal tract organs.

The chronic diseases of respiratory organs are found in $17.3 \%$ of children at the comparison PEO and in $28.8 \%$ at the observation PEO $(p=0.07)$ (table 11). It should be noted that the relative risk of he development of chronic inflammatory and proliferative processes in the upper respiratory tracts in the observation PEO children was 1.5 times higher 
than at the comparison PEO $(O R=1.47 ; D I=1.11-$ 1.36; $p=0.04$ ), and the allergic diseases (MKB-10: $\mathrm{J} 39.8, \mathrm{~J} 45.0)$ - by 2.3 times $(O R=2.25 ; D I=1.37-$ $2.48 ; p=0.03)$. The allergic skin diseases (MKB10: L20.8) were diagnosed in 2.9 and $8.2 \%$ of children respectively $(p=0.11)$ (see table 11$)$. In general, the relative risk of the allergic pathology development in the observation PEO children by more than 2.5 times exceeded the same at the comparison PEO $(O R=2.52 ; D I=1.26-2.71 ; p=0.02)$.

The most significant differences in the structure of chronic pathology in the children of examined children educational organizations were established under class "Diseases of nervous system": at the comparison PEO this type of pathology is diagnosed in $25.0 \%$ of visitors, since at the observation $\mathrm{PEO} \quad-$ in $53.4 \% \quad(p \leq 0.001)$.

Table 10

Number of children with low level of the cognitive functions development (\%)

\begin{tabular}{|l|c|c|c|}
\hline \multicolumn{1}{|c|}{ Assessment } & Comparison PEO & $\begin{array}{c}\text { Observation } \\
\text { PEO }\end{array}$ & $\begin{array}{c}\text { Credibility of differences between } \\
\text { groups }\end{array}$ \\
\hline Perception & 13,7 & 12,5 & 0,7 \\
\hline Spatial praxis & 31,8 & 31,3 & 0,97 \\
\hline Kinesthetic organization of movements & 36,4 & 37,5 & 0,95 \\
\hline Attention & 36,4 & 56,3 & $\mathbf{0 , 0 2}$ \\
\hline
\end{tabular}

Table 11

Frequency of registration of chronic diseases in the examined children (\%)

\begin{tabular}{|c|c|c|c|c|}
\hline \multirow[b]{2}{*}{ Group of diseases } & \multirow[b]{2}{*}{ Clinical entity } & \multicolumn{2}{|c|}{ PEO } & \multirow{2}{*}{$\begin{array}{l}\text { Credibility of dif- } \\
\text { ferences between } \\
\text { groups }\end{array}$} \\
\hline & & comparison & observation & \\
\hline \multicolumn{2}{|c|}{ Respiratory diseases (J00-99) } & 17,3 & 28,8 & 0,07 \\
\hline & $\begin{array}{l}\text { Hypertrophy of palatine tonsils, adenoiditis } \\
\text { (J35.1) }\end{array}$ & 9,6 & 13,7 & 0,40 \\
\hline & Respiratory allergosis (J39.8) & 7,7 & 13,7 & 0,19 \\
\hline & Bronchial asthma (J 45.0) & 0 & 1,4 & 0,23 \\
\hline Skin diseases (L20-92) & Atopic dermatitis (L20.8) & 2,9 & 8,2 & 0,11 \\
\hline \multicolumn{2}{|c|}{ Diseases of the nervous system (G00-99) } & 25,0 & 53,4 & $\leq \mathbf{0 , 0 0 1}$ \\
\hline & Enuresis (F98) & 6,7 & 12,3 & 0,20 \\
\hline & Asthenoneurotic syndrome (G93.8) & 6,7 & 17,8 & $\mathbf{0 , 0 2}$ \\
\hline & Attention deficit hyperactivity disorder (F90) & 1,0 & 6,9 & 0,3 \\
\hline & Asthenovegetative syndrome (G90.8) & 9,6 & 13,7 & 0,4 \\
\hline & Delay of neuropsychic development (F88) & 1,0 & 2,7 & 0,4 \\
\hline \multicolumn{2}{|c|}{ Gastrointestinal diseases (K00-93) } & 68,3 & 61,6 & 0,36 \\
\hline & Biliary dysfunction (K83.8) & 12,5 & 15,1 & 0,62 \\
\hline & Chronic gastroduodenitis (K29.9) & 1,9 & 1,0 & 0,63 \\
\hline & Dyspepsia syndrome (K30.0) & 53,9 & 45,2 & 0,25 \\
\hline
\end{tabular}

Table 12

Results of ultrasound examination of gastrointestinal tract organs in the examined children (\%)

\begin{tabular}{|l|c|c|c|}
\hline \multirow{2}{*}{\multicolumn{1}{|c|}{ Results }} & \multicolumn{2}{c|}{ PEO } & $\begin{array}{c}\text { Credibility of differences be- } \\
\text { tween groups }\end{array}$ \\
\cline { 2 - 3 } & comparison & observation & $\mathbf{0 , 0 5}$ \\
\hline Ultrasound liver standard & 43 & 29 & $\mathbf{0 , 0 5}$ \\
\hline Increase of linear dimensions & 57 & 71 & $\leq \mathbf{0 , 0 0 1}$ \\
\hline Normal echostructure & 71 & 43 & $\leq \mathbf{0 , 0 0 1}$ \\
\hline Changed echostructure & 29 & 57 & $\leq \mathbf{0 5}$ \\
\hline \multicolumn{1}{|c|}{ diffusive changes of liver } & 29 & 43 & $\leq \mathbf{0 0 1}$ \\
\hline - reactive changes & 0 & 14 & $\leq \mathbf{0 0 1}$ \\
\hline Ultrasound gall bladder standard & 0 & 14 & $\mathbf{0 , 0 0 1}$ \\
\hline Signs of dyscholia & 29 & 86 & $\mathbf{0 0 1}$ \\
\hline Ultrasound stomach sweetbread standard & 29 & 29 & $\mathbf{0 , 0 0 8}$ \\
\hline Reactive changes of stomach sweetbread & 57 & 71 & \\
\hline
\end{tabular}


Distribution of examined children under the health groups (\%)

\begin{tabular}{|c|c|c|c|}
\hline \multirow{2}{*}{ Health group } & \multicolumn{2}{|c|}{ PEO } & $\begin{array}{c}\text { Credibility of differences be- } \\
\text { tween groups }\end{array}$ \\
\cline { 2 - 4 } & comparison & observation & 0,75 \\
\hline I & 6,7 & 5,5 & $\mathbf{0 , 0 3}$ \\
\hline II & 87,5 & 75,3 & $\mathbf{0 , 0 0 6}$ \\
\hline
\end{tabular}

The functional disorders of nervous system (asthenoneurotic syndrome (MKB-10: G93.8), attention deficit hyperactivity disorder (MKB-10: F90), asthenovegetative syndrome (MKB-10: G90.8)) were found in $38.4 \%$ of the observation PEO children and only in $17.3 \%$ of the comparison PEO children $(p=0.002)$. The relative risk for the development of functional disorders of nervous system in the observation PEO children was 3.0 times higher $(O R=2.97 ; D I=1.49$ 4.96; $p=0.01$ ).

The gastrointestinal diseases (MKB-10: K00K93) were found in the chidren of examined kindergartens with close frequency - in $68.3-61.6 \%$ $(p=0.36)$, herewith the prevailing option of pathology included the dyspepsia syndrome (MKB-10: K30.8) diagnosed in 53.9-61.6\% ( $p=0.36)$.

The data from the ultrasound examination of the abdominal cavity organs demonstrated that the visitors of observation PEO statistically more credibly had the increased linear dimensions of liver, changes of its echostructure (diffusive or reactive), signs of dyscholia and reactive changes of stomach sweetbread $(p \leq 0.001-0.05)$ (table 12).

The complex assessment of somatic status allowed for establishing that the only $6.7 \%$ of the comparison PEO children and $5.5 \%$ of the observation PEO children had the first health group $(p=0.75)$; the second group was credibly often recorded in the comparison PEO children (87.5 versus $75.3 \%, p=0.03$ ), and the number of children with systemic polyorganic pathology (III health group) was credibly bigger at the observation PEO (19.2 versus $5.8 \%, p=0.006$ ) (table 13).

In general, $94.2 \%$ of the comparison PEO children had the first or second health group, since at the observation PEO the number of such children was $80.8 \%$; the relative risk for the development of systemic polyorganic pathology in the examined PEO children was 4.0 times higher than at the comparison PEO $(O R=3.85 ; D I=2.17-6.11$; $p=0.04$ ).

Conclusions. The results of conducted study demonstrated that the formation of "compacted" groups (30 children) at the standard PEOs significantly worsens the sanitary and hygienic conditions for the staying of children: the indicator of the playing premise area per 1 child in $40 \%$ of cases does not meet the requirements of SanPiN 2.4.1.3049-13; the level of acoustic impact during the playing lessons achieves 75-80 dBA; the air of playing rooms contains phenol and formaldehyde the concentrations of which by 2.24.6 times exceed the average daily maximum permissible concentration, and the total nicrobial count in the air of playing rooms reaches $1360.91 \pm 550.49 \mathrm{CFU} / \mathrm{m}^{3}$, herewith $30 \%$ of samples contain the opportunistic flora (St. aureus) with microbial count of $4-20 \mathrm{CFU} / \mathrm{m}^{3}$.

Data of the complex clinical and functional examination of children visiting the "compacted" PEOs evidence that the increased representation of groups by 1.5-2.2 times increases the risk for the formation of the disorders of the physical developmet and biological maturity rates in children; by 4.0-6.6 times - reduction of adaptive reserve of the cardiovascular system; by 7 times - disorders of the functions of upper respiratory tracts; by 3 times - development of functional disorders of nervous system; by 4 times - formation of systemic polyorganic pathology that in aggregate contributes to the increased morbidity with allergic diseases of repisratory organs and skin, chronic inflammatory diseases of rhinopharynx and tonsils, bacterial, intestinal and quarantine (chicken pox, scarlet fever) infections, functional disorders of nervous system and contact helminthosis. The obtained data evidence the necessity to establish the standard in relation to the optimum representation of groups at the typical PEOs. 


\section{References}

1. Vejnih P.A., Ishhenko A.I., Shhuchinov L.V. Determinanty sistemy vospitanija i obuchenija, opredeljajushhie zdorov'e doshkol'nikov v sovremennyh uslovijah [Determinants of the upbringing and education system defining the health of preschool children in the modern conditions]. Nauka o cheloveke: gumanitarnye issledovanija, 2013, no. 4 (14), pp. 65-72.

2. General'nomu prokuroru RF ob izmenenijah v SanPiNah po predel'noj napolnjaemosti grupp v detskih sadah ot obshhestvennogo dvizhenija «Rossijskim detjam dostupnoe doshkol'noe obrazovanie» [To the Prosecutor General of the Russian Federation on the changes to SanPiNs on the threshold representation of groups in the kindergartens from the social movement "Available Preschool Education for the Russian Children"]. Available at: http: //rdddo.ru/novosti/473.

3. Zibarev P., Zubkova T. Jekologicheskaja bezopasnost' polimernyh stroitel'nyh materialov. Analiz gazovydelenij [Environmental safety of polymeric construction materials. Gas emission analysis]. Jekologija promyshlennogo proizvodstva, 2007, no. 2, pp. 27-33.

4. Ishhenko A.I., Kozyreva F.U. Osnovy monitoringa zdorov'ja doshkol'nikov v sovremennyh uslovijah [Basics of the preschool children health monitoring in the modern conditions]. Nauka o cheloveke: gumanitarnye issledovanija, 2013, no. 4 (14), pp. 72-78.

5. Medvedeva S.A. Vyravnivanie psihofizicheskogo razvitija starshih doshkol'nikov sredstvami zdorov'esberegajushhih meroprijatij [Leveling of the psycho-physiological development of over-fives using the health-saving measures]. Uchenye zapiski universiteta im. P.F. Lesgafta, 2014, no. 2 (108), pp. 113-119.

6. Nazarova E.V., Zhukova E.A. Kuzmichev Ju.G. Sostojanie i dinamika zdorov'ja detej, poseshhajushhih doshkol'nye obrazovatel'nye uchrezhdenija [Condition and dynamics of the health of children visiting the preschool educational institutions]. Zdravoohranenie Rossijskoj Federacii, 2013, no. 1, pp. 40-42.

7. Nikulkina D.V. Psihologicheskoe zdorov'e detej 5-6 let, vospityvajushhihsja v obrazovatel'nyh uchrezhdenijah raznogo tipa [Psychological health of children in the age of 5-6 years brought up at the educational institutions of different types]. Psihologija obrazovanija v politkul'turnom prostranstve, 2014, no. 25 (1), pp. 38-45.

8. Metodicheskie rekomendacii Goskomsanjepidnadzora RF «Ocenka fizicheskogo razvitija i sostojanija zdorov'ja detej i podrostkov, izuchenie mediko-social'nyh prichin formirovanija otklonenij v zdorov'e» [Guidelines of the State Committee on Sanitary and Epidemiology Surveillance of the Russian Federation "Assessment of physiological development and condition of health of children and teenagers and studying the medical and social reasons for the health deviations formation"]. Moscow, 1996, $28 \mathrm{p}$.

9. Pavlenko T.N., Kapcova G.B., Maleeva N.P. Dinamika individual'nogo zdorov'ja, uslovija i kachestvo zhizni detej, poseshhajushhih detskie doshkol'nye obrazovatel'nye uchrezhdenija [Individual health dynamics, conditions and quality of life of children visiting children's preschool educational institutions]. Zdorov'e naselenija $i$ sreda obitanija, 2013, no. 6, pp. 35-38.

10. Stepanova M.I. K voprosu o normirovanii napolnjaemosti doshkol'nyh grupp [On the issue concerning the standardization of the number of children in the preschool groups]. SanJepidemKontrol', 2012, no. 4, pp. 14-19.

11. Razinov Ju.I., Strizhak A.P. Perspektivy podgotovki sportivnogo rezerva v svete fizicheskogo sostojanija sovremennyh detej 4-7 let [Prospects for the training of sports reserve in terms of the physical condition of the modern children in the age of 4-7 years]. Uchenye zapiski universiteta im. P.F. Lesgafta, 2012, vol. 91, pp. 129-133.

12.Tarmaeva I.Ju., Pogorelova I.G. Gigienicheskaja ocenka uslovij prebyvanija i sostojanija zdorov'ja doshkol'nikov g.Irkutska [Hygienic assessment of the conditions of staying and health of the preschool children in Irkutsk]. Sibirskij medicinskij zhurnal, 2014, no. 2, pp. 86-89.

13. Chajchenko M.V., Zolotova M.Ju. Uroven' narushenij v sostojanii oporno-dvigatel'nogo apparata u detej doshkol'nyh obrazovatel'nyh uchrezhdenij g. Kolomny i Kolomenskogo rajona Moskovskoj oblasti [The level of disorders in the locomotive system condition of children in the preschool educational institutions of Kolomna and Kolomensky district of Moscow region]. Izvestija Tul'skogo gosudarstvennogo universiteta. Fizicheskaja kul'tura $i$ sport, 2013, no. 2, pp. 175-181.

14.Böhm M, Salem MZ, Srba J. (2012) Formaldehyde emission monitoring from a variety of solid wood, plywood, blockboard and flooring products manufactured for building and furnishing materials. J. Hazard Mater, 2012, vol. 30 (221-222), pp. 68-79. 